\title{
OPTIMALISASI PERAN DEWAN PENGAWAS SYARIAH (DPS) PADA PERUSAHAAN ASURANSI SYARIAH DI INDONESIA
}

\author{
Muhammad Gary Gagarin Akbar \\ Universitas Buana Perjuangan Karawang \\ Email : Gagaringary@gmail.com
}

\begin{abstract}
Abstrak
In Sharia Financial Institute, especially sharia insurance has Sharia Supervisory Board to provide supervisor and ensure that practice of Sharia Financial Institute is in line with sharia principles. In practice, the role of Sharia Supervisory Board not optimal and still weak performing their duties, so that impact to the development of sharia insurance. On that basis the role of Sharia Supervisory Board should be optimized to promote sharia industri in indonesia because provision about Sharia Supervisory Board have been regulated in many regulation. This article to analyze the problem faced Sharia Supervisory Board and found a solution to optimum role of Sharia Supervisory Board.
\end{abstract}

Keywords : Sharia Insurance and Sharia Supervisory Board

\begin{abstract}
Pada suatu Lembaga Keuangan Syariah, khususnya asuransi syariah memiliki Dewan Pengawas Syariah (DPS) yang berfungsi untuk memberikan pengawasan dan memastikan bahwa usaha yang dijalankan suatu tersebut sudah sesuai dengan prinsip-prinsip syariah. Dalam praktiknya, peran DPS ini belum optimal dan masih lemah dalam menjalankan tugasnya sehingga berdampak pada perkembangan asuransi syariah. Atas dasar tersebut peran dari DPS sudah seharusnya dapat dioptimalisasi untuk memajukan industri asuransi syariah di Indonesia karena ketentuan mengenai DPS sudah diatur sedemikian rupa di dalam peraturan perundang-undangan. Tulisan ini bertujuan untuk menganalisa permasalahan yang dihadapi oleh DPS dan menemukan solusi untuk mengoptimalisasi peran dari DPS.
\end{abstract}

Kata Kunci : Asuransi Syariah dan Optimalisasi Dewan Pengawas Syariah 


\section{A. Pendahuluan}

Islam adalah suatu sistem hidup yang lengkap dan universal untuk menyusun dan memberikan arahan yang dinamis dan mudah untuk semua aspek kehidupan, termasuk bisnis dan transaksi keuangan. ${ }^{1}$ Fenomena yang muncul saat ini di Indonesia adalah keberadaan ekonomi syariah. Dewasa ini perkembangan ekonomi syariah di Indonesia semakin hari semakin pesat. Sebagai negara yang mayoritas penduduknya beragama Islam, kehadiran ekonomi syariah di Indonesia disambut dengan sangat positif oleh masyarakat. Salah satu ekonomi syariah yang sedang berkembang tersebut adalah di bidang asuransi.

Kata asuransi diambil dari bahasa Belanda, yaitu "assurantie", yang dalam bahasa hukum Belanda disebut dengan "verzekering" yang berarti pertanggungan. Istilah itu kemudian berkembang menjadi "assuradeur" yang berarti penanggung dan takaful, ta'min, dan Islamic insurance. Takaful memiliki arti saling menanggung antar umat manusia sebagai makhluk sosial. Ta'min berasal dari kata amanah, yang berarti memberikan perlindungan, ketenangan, rasa aman, serta bebas dari rasa takut. Adapun Islamic insurance mengandung makna "pertanggungan" atau saling menanggung. ${ }^{2}$

Fatwa Dewan Syariah Nasional Nomor 21/DSN-MUI/X/2001 tentang Pedoman Umum Asuransi Syariah disebutkan bahwa asuransi syariah (ta'min, takaful, atau tadhamun) adalah usaha saling melindungi dan tolong menolong diantara sejumlah orang/pihak melalui investasi dalam bentuk aset dan/atau tabarru' yang memberikan pola pengembalian untuk menghadapi risiko tertentu melalui akad (perikatan) yang sesuai dengan syariah. Adapun akad (perjanjian) syariah adalah akad yang tidak mengandung gharar (penipuan), maysir, riba, zhulm, risywah, barang haram, dan maksiat. ${ }^{3}$ kegiatan asuransi adalah kegiatan yang terjadi antara pihak tertanggung dengan pihak penangung dalam memberikan ganti rugi atas suatu kerugian atau kerusakan. Asuransi syariah secara umum kegiatannya tidak berbeda dengan kegiatan asuransi pada umumnya atau asuransi konvensional. Hal yang membedakan antara asuransi syariah dengan asuransi konvensional itu terletak pada prinsip kerja yang digunakan, jika asuransi syariah menggunakan prinsip saling tolong menolong (ta'awun) dan kebajikan (tabarru') sedangkan dalam konvensional tidak menggunakan

\footnotetext{
${ }^{1}$ Bagya Agung Prabowo dan Jasri Bin Jamal, Peranan Dewan Pengawas Syariah terhadap Praktik Kepatuhan Syariah dalam Perbankan Syariah di Indonesia, Jurnal Hukum IUS QUIA IUSTUM, Vol.24, No.1, 2017, hlm.114

${ }^{2}$ Amran Suadi, Abdul Manan Ilmuan dan Praktisi Hukum (Kenangan Sebuah Perjuangan), (Jakarta: Kencana, 2016), hlM.345

${ }^{3}$ Ibid.
} 
prinsip ini. Dalam hal penggunaan dana asuransi, asuransi syariah menggunakan dana yang telah terkumpul tersebut diinvestasikan dalam bentuk sistem bagi hasil (mudharabah) sedangkan dalam konvensional dana yang telah terkumpul diinvestasikan kepada usaha yang masih menggunakan sistem bunga (profit oriented).

Asuransi syariah memiliki produk-produk yang cukup menarik bagi masyarakat, dikarenakan akad-akad yang ditawarkan dalam produk asuransi syariah tersebut didasarkan pada syariat Islam. Dalam implementasi atau pelaksanaannya, asuransi syariah dituntut agar menerapkan prinsip-prinsip syariah sebagaimana yang telah ditentukan dalam Alqur'an dan Al-Hadis. Pada praktiknya ada beberapa kasus justru implementasi dari asuransi syariah ini tidak sepenuhnya sesuai dengan syariat Islam sehingga nasabah atau masyarakat merasa dirugikan. Di dalam beberapa kasus ditemukan bahwa pada implementasi asuransi syariah ada praktik bahwa nasabah harus tunduk pada ketentuan perusahaan asuransi syariah tersebut dan ketentuan-ketentuan tersebut sudah dibakukan oleh pihak perusahaan. Kemudian selanjutnya kasus yang terjadi adalah adanya kemungkinan perusahaan asuransi syariah menginvestasikan dana nasabah kepada lembaga konvensional yang menjalankan usaha dan bisnis menggunakan praktik ribawi untuk memperoleh keuntungan. Selain itu, jika nasabah asuransi syariah tersebut tidak dapat lagi melanjutkan pembayaran premi, sehingga seringkali uang nasabah yang disetor tersebut menjadi hilang atau hangus tanpa adanya surat pemberitahuan kepada nasabah atau pemegang polis. Seharusnya dana tersebut dikembalikan lagi kepada nasabah sesuai dengan kesepakatan bagi hasil yang telah disepakati.

Untuk menjaga agar perusahaan asuransi syariah benar-benar menerapkan nilainilai Islam dan tidak menyimpang, maka dalam menjalankan aktivitasnya selalu berada dibawah pengawasan Dewan Pengawas Syariah (DPS). Keberadaan DPS inilah yang membedakan antara lembaga konvensional dengan lembaga syariah. Dewan Pengawas Syariah bertugas memastikan semua produk dan kegiatan Lembaga Keuangan Syariah termasuk asuransi syariah telah memenuhi prinsip syariah. DPS dipercaya untuk memastikan agar Lemabaga Keuangan Syariah patuh pada aturan dan prinsip Islam.

Peran dan fungsi Dewan Pengawas Syariah (DPS) saat ini belum berjalan optimal dalam mengawasi Lembaga Keuangan Syariah khususnya dalam hal ini dibidang asuransi syariah. Permasalahan yang menjadi penyebab kurang optimalnya antara lain masalah Sumber Daya Manusia (SDM) dan kinerja. Hal tersebut dikarenakan dalam pengangkatan DPS pada unit syariah atau khususnya pada asuransi syariah tidak 
didasarkan atas kompetensi yang dimiliki terkait dengan operasional asuransi syariah tetapi hanya didasarkan atas kharisma atau ulama yang banyak dikenal oleh publik. Selain itu, kinerja DPS pada perusahaan asuransi juga harus dipertanyakan kembali karena seringkali DPS jarang datang langsung untuk mengawasi dan memeriksa kegiatan usaha perusahaan asuransi syariah sehingga sampai saat ini masih saja terdapat penerapan asuransi syariah yang tidak sesuai dengan syariat Islam baik sebagian maupun seluruhnya. Permasalahan pada aspek pengawasan ini dapat berakibat fatal karena akan berdampak munculnya ketidakpercayaan masyarakat kepada lembagalembaga bisnis berlabel syariah secara keseluruhan.

\section{B. Tinjauan Hukum Islam tentang Asuransi}

Bangunan yang membentuk adanya asuransi syariah didasarkan pada prinsip dasar dari nilai yang berlaku pada diri manusia. Manusia terlahir dibekali dengan dua kekuatan, yaitu kekuatan pembentuk yang berasal dari Tuhan yang cenderung berbuat baik dan kekuatan pembentuk yang berasal dari materi (unsur tanah). Nilai tersebut merupakan pembawaan manusia sejak lahir yang bersifat alami (nature) yang terikat oleh aturan-aturan yang berasal dari Allah SWT. Dengan berbekal kedua kekuatan tersebut, manusia dituntut untuk membaca segala norma atau aturan-aturan Tuhan yang ada di alam semesta, sehingga segala gerak yang yang dilakukan manusia tertuju pada ketentuan yang digariskan oleh-Nya. ${ }^{4}$

Sebagai makhluk yang lemah, manusia harus senantiasa sadar bahwa keberadaannya tidak akan mampu hidup sendiri tanpa bantuan orang lain atau sesamanya. Solusinya adalah firman Allah SWT dalam QS. Al-Maidah (5):2

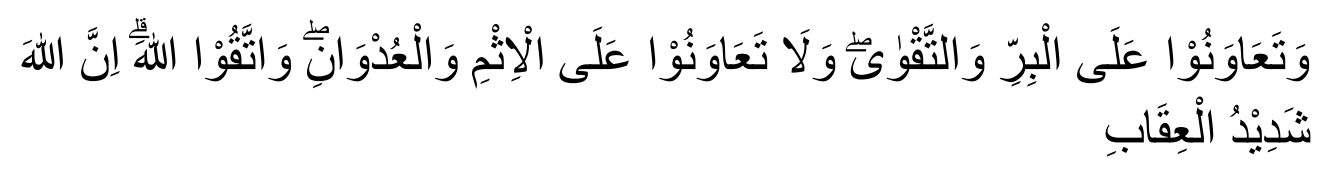

Artinya: “... Tolong menolonglah kamu dalam (mengerjakan) kebaikan dan takwa, dan jangan tolong menolong dalam berbuat dosa atau pelanggaran. Dan bertakwalah kamu kepada Allah, sesungguhnya Allah amat berat siksa-Nya". (QS. Al-Maidah (5): 2)

${ }^{4}$ AM. Hasan Ali, Asuransi dalam Perspektif Hukum Islam (Suatu Tinjauan Analisis Historis, Teoritis, dan Praktis), (Jakarta: Kencana, 2004), hal.98 
Dengan ayat ini, manusia dituntun oleh Allah SWT agar selalul berbuat tolong menolong (ta'awun) antar sesamanya dalam kebaikan dan didasari atas nilai takwa kepada Allah SWT. Hal ini merupakan satu prinsip dasar yang harus dipegang manusia dalam menjalani kehidupannya di atas permukaan bumi ini. Dengan saling melakukan tolong menolong ( $t a$ 'awun), manusia telah menjalankan satu fitrah dasar yang diberikan Allah SWT kepadanya. Prinsip dasar inilah yang menjadi salah satu nilai filosofi dari berlakunya asuransi syariah. ${ }^{5}$

Di sisi lain manusia mempunyai sifat lemah dalam menghadapi kejadian yang akan datang. Sifat lemah tersebut berbentuk ketidaktahuannya terhadap kejadian yang akan menimpa pada dirinya. Manusia tidak dapat memastikan bagaimana keadaannya pada waktu di kemudian hari (future time). ${ }^{6}$ Hal tersebut bisa kita lihat pada firman Allah SWT dalam QS. Al-Taghaabun (64): 11 dan QA.Luqman (31):34.

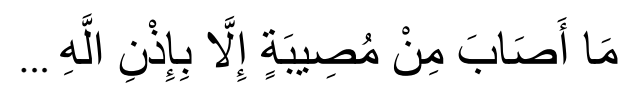

Artinya: "Tidak ada sesuatu musibah pun yang menimpa seseorang kecuali dengan izin Allah..." (QS. Al-Taghaabun (64): 11)

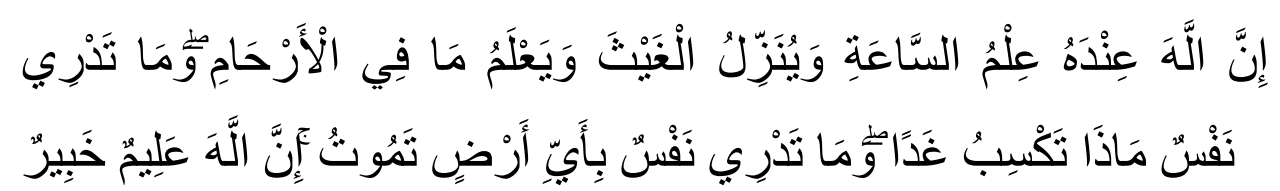

Artinya: "Seseungguhnya Allah, hanya pada sisi-Nya sajalah pengetahuan tentang hari kiamat; dan Dia lah yang menurunkan hujan, dan mengetahui apa yang ada dalam rahim. Dan tiada seorang pun yang dapat mengetahui (dengan pasti) apa yang akan diusahakannya besok; dan tiada seorang pun yang dapat mengetahui di bumi mana ia akan mati. Sesunggunya Allah Maha mengetahui lagi maha mengenal." (QS.Luqman (31): 34)

Dasar-dasar hukum asuransi ekonomi syariah adalah sebagai berikut:

a) Alquran

Alquran tidak menyebutkan secara tegas ayat yang menjelaskan tentang praktik asuransi syariah. Alquran hanya mengakomodasi beberapa ayat yang mempunyai muatan nilai-nilai dasar yang ada dalam praktik asuransi, antara lain nilai dasar untuk tolong menolong, kerja sama, atau semangat untuk melakukan proteksi terhadap peristiwa atau kejadian yang merugikan di masa

\footnotetext{
${ }^{5}$ Ibid, hal.100

${ }^{6}$ Ibid.
} 
mendatang. Berdasarkan dasar ini, praktik asuransi tidak di larang dalam syariat Islam. Ayat yang mengandung nilai-nilai terkait asuransi tersebut antara lain surat Al-Maidah ayat 2, Al-Baqarah ayat 261, dan Al-Taghaabun ayat 11 .

b) Al-Hadis

Hadis yang berhubungan dengan nilai-nilai yang terdapat dalam asuransi syariah antara lain:

Dari Abu Hurairah r.a: "Barangsiapa yang melepaskan dari seorang Muslim suatu kesulitan di dunia, Allah SWT akan melepaskan kesulitan darinya pada hari kiamat, dan Allah SWT senantiasa menolong hambaNya selama ia (suka) menolong saudaranya." (Hadis Riwayat Muslim).

Hadis ini kaitannya dengan asuransi terlihat adanya anjuran agar melaksanakan pembayaran premi dalam bentuk dana sosial (tabarru').

Kemudian, ada Hadis yang menganjurkan untuk meninggalkan ahli waris yang kaya.

Dari Amir bin Sa'ad bin Abi Waqasy, telah bersabda Rasululah SAW: "Lebih baik jika engkau meninggalkan anak-anak kamu (ahli waris) dalam keadaan kaya raya, daripada meninggalkan mereka dalam keadaan miskin (kelaparan) yang meminta-minta kepada manusia lainnya ." (Hadis Riwayat Bukhari).

Hadis ini menunjukkan bahwa Rasulullah SAW sangat memperhatikan kehidupan yang akan terjadi di masa mendatang dengan cara mempersiapkan bekal yang dibutuhkan sejak dini kepada para ahli waris atau keturunannya.

c) Undang-Undang

Undang-Undang No. 2 Tahun 1992 sebagaimana telah diubah dengan Undang-Undang Nomor 40 Tahun 2014 tentang Usaha Perasuransian.

d) Fatwa Dewan Syariah Nasional No.21/DSN-MI/X/2001

e) Keputusan Menteri Keuangan RI No. 426/KMK.06/2003

f) Peraturan Ketua Badan Pengawas Pasar Modal dan Lembaga Keuangan Nomor : PER-08 /BL/2011 Tentang Bentuk Dan Tata Cara Penyampaian Laporan Hasil Pengawasan Dewan Pengawas Syariah Pada Perusahaan Asuransi Atau Perusahaan Reasuransi Yang Menyelenggarakan Seluruh Atau Sebagian Usahanya Dengan Prinsip Syariah. 


\section{Fungsi dan Peranan DPS}

Untuk lebih mengefektifkan peran Dewan Syariah Nasional (DSN), pada Lembaga Keuangan Syariah (LKS) dibentuk Dewan Pengawas Syariah (DPS) sebagai perwakilan DSN pada lembaga keuangan yang bersangkutan. DPS adalah suatu badan yang diberi wewenang untuk melakukan supervisi atau pengawasan dan melihat secara dekat aktivitas lembaga keuangan syariah agar lembaga tersebut senantiasa mengikutiaturan dan prinsip-prinsip syariah. Oleh karena itu, DPS pada dasarnya merupakan perpanjangan tangan DSN dalam merealisasikan fatwa-fatwa yang telah diputuskan oleh DSN. DPS berperan sebagai pengawas dari lembaga-lembaga keuangan syariah, yaitu bank syariah, asuransi syariah, pasar modal syariah, dan lainlain, agar semua lembaga tersebut berjalan sesuai dengan tuntutan syariat Islam. Pengawasan selain pada aspek produk-produk keuangan syariah, juga meliputi manajemen dan administrasi lembaga keuangan syariah agar sesuai dengan syariah. Di sisi lain, DPS adalah bagaian dari lembaga keuangan syariah yang bersangkutan yang penempatannya atas persetujuan $\mathrm{DSN}^{7}$

Peran DPS adalah mengawasi kegiatan usaha lembaga keuangan syariah agar sesuai dengan ketentuan dan prinsip syariah yang telah ditawarkan oleh DSN. Sedangkan, fungsi utamanya adalah pertama, sebagai penasehat dan pemberi saran kepada direksi, pimpinan unit usaha syariah, dan pimpinan kantor cabang syariah mengenai hal-hal yang terkait dengan aspek syariah; dan kedua, sebagai mediator antara lembaga keuangan syariah dengan DSN dalam mengkomunikasikan usul dan saran pengembangan produk dan jasa dari lembaga keuangan syariah yang memerlukan kajian dan fatwa dari DSN. ${ }^{8}$

Sebetulnya, tugas mengawasi dan mengarahkan lembaga-lembaga keuangan syariah untuk mendorong penerapan prinsip-prinsip syariah dalam kegiatan perekonomian dan keuangan adalah tugas dari Dewan Syariah Nasional yang berkedudukan di Jakarta. Namun, karena keterbatasan jumlah anggotanya dan jumlah keuangan syariah semakin bertambah banyak yang tersebar di seluruh wilayah nusantara, sehingga pengawasannya diserahkan kepada Dewan Pengawas Syariah (DPS). DPS berkewajiban secara langsung melihat pelaksanaan suatu lembaga

\footnotetext{
${ }^{7}$ Akhmad Faozan, Optimalisasi Peran Dewan Pengawas Syariah Pada Lembaga Keuangan Syariah, Jurnal Ekonomi Islam, el-Jizya Vol.II, No.1, Janauari 2014, hlm.25-26

${ }^{8}$ Ibid.
} 
keuangan syariah agar tidak menyimpang dari ketentuan yang telah di fatwakan oleh DSN Majelis Ulama Indonesia (MUI) yang berkedudukan di Jakarta. ${ }^{9}$

DPS yang merupakan perwakilan DSN yang ditempatkan pada lembaga keuangan syariah mempunyai beberapa peran sebagai berikut: ${ }^{10}$

1) Mengikuti fatwa DSN;

2) Merumuskan permasalahan yang memerlukan pengesahan DSN;

3) Melaporkan kegiatan usaha serta perkembangan lembaga keuangan syariah yang diawasinya kepada DSN sekurang-kurangnya satu kali dalam setahun.

Peran pokok DPS pada setiap lembaga keuangan syariah adalah: ${ }^{11}$

1) Memberikan nasihat dan saran kepada direksi, pimpinan unit usaha syariah dan pimpinan kantor cabang lembaga keuangan syariah mengenai hal-hal yang berkaitan dengan aspek syariah.

2) Melakukan pengawasan, baik secara aktif maupun pasif, terutama dalam pelaksanaan fatwa DSN serta memberikan pengarahan/pengawasan atas produk/jasa dan kegiatan usaha agar sesuai prinsip syariah.

Sebagai mediator antara lembaga keuangan syariah dengan DSN dalam mengkomunikasikan usul dan saran pengembangan produk dan jasa dari lembaga keuangan syariah yang memerlukan kajian dan fatwa dari DSN.

\section{Optimalisasi Peran DPS Pada Perusahaan Asuransi Syariah di Indonesia}

Dewan pengawas syariah merupakan profesi yang lahir dan besar dari tuntutan publik akan adanya suatu jaminan akan penerapan konsistensi dan loyalitas dalam syariat islam. Jasa profesional dari DPS merupakan kewajiban yang harus diemban olehnya sebagai pihak yang diserahi tanggung jawab untuk membuat pelaporan dan verifikasi yang mana nantinya output yang telah dihasilkannya tidak hanya digunakan oleh klien, namun juga oleh pihak ketiga atau public (investor/pemegang saham, kreditor, pemerintah, masyarakat dll). Khususnya dalam hal pengendalian dan pengambilan keputusan decision making. Oleh karenanya, posisi DPS adalah sangat vital karena meski mereka bekerja selayaknya auditor untuk kepentingan klien (bank)

\footnotetext{
${ }^{9}$ Ibid, hlm.28

${ }^{10}$ Keputusan Dewan Syariah Nasional Majelis Ulama Indonesia No.02 Tahun 2000 Pasal 4 Fungsi dan Tugas DPS No.2

${ }^{11}$ Keputusan Dewan Syariah Nasional Majelis Ulama Indonesia No.02 Tahun 2000 Pasal 4 Fungsi dan Tugas DPS No.1
} 
dan juga untuk kepentingan pihak ketiga yang memiliki kepentingan terhadap laporan keuangan. Setiap pernyataan yang dikeluarkannya atau setiap apa yang difatwakan/diputuskan adalah menyangkut sesuatu yang sangat prinsipil karena terkait dengan aqidah dan keyakinan dari orangorang yang berada dalam lingkup kerjasama dengan organisasi yang menaungi mereka dan pihak ketiga. ${ }^{12}$

Industri Keuangan Non Bank (IKNB) Syariah yang diawasi oleh Otoritas Jasa Keuangan (OJK) meliputi Perusahaan Perasuransian Syariah, Lembaga Pembiayaan Syariah, Dana Pensiun Syariah, dan Lembaga Keuangan Syariah Khusus. Perusahaan perasuransian syariah terdiri dari perusahaan asuransi dan perusahaan reasuransi yang menjalankan sebagian atau keseluruhan kegiatannya berdasarkan prinsip syariah.

Berdasarkan data yang diperoleh dari OJK terkait Laporan Perkembangan Keuangan Syariah tahun 2016, jumlah asuransi syariah semakin hari semakin bertambah. Jumlah asuransi syariah dapat kita lihat pada tabel di bawah ini.

Tabel 1.1

\begin{tabular}{|c|c|}
\hline Tahun & $\begin{array}{c}\text { Jumlah Perusahaan Perasuransian } \\
\text { Syariah }\end{array}$ \\
\hline 2012 & 45 \\
\hline 2013 & 49 \\
\hline 2014 & 49 \\
\hline 2015 & 55 \\
\hline 2016 & 58 \\
\hline
\end{tabular}

Berdasarkan data tersebut di atas dapat kita ketahui bahwa perkembangan asuransi syariah setiap tahun mengalami peningkatan walaupun peningkatannya tidak terlalu signifikan. Dalam 5 (lima) tahun jumlah perusahaan asuransi hanya bertambah sebanyak 13 (tiga belas) perusahaan saja. Selama kurun waktu 5 (lima) tahun terakhir, perkembangan perusahaan perasuransian syariah mencapai pertumbuhan rata-rata sebesar $6,25 \%$. Tingkat pertumbuhan tertinggi terjadi pada tahun 2015 yang mencapai 12,24\% sedangkan tingkat pertumbuhan terendah terjadi pada tahun 2014 dengan tingkat pertumbuhan sebesar $0,00 \%$ (nihil). Peningkatan jumlah industri perasuransian

${ }^{12}$ Eko Adi Widyanto, Peran Independensi Dewan Pengawas Syariah Terhadap Loyalitas Penerapan Syariat Islam, Jurnal Eksis, Vol.6 No.2, Agustus 2010:1440-1605. 
yang tertinggi terjadi pada perusahaan asuransi umum syariah, yang meningkat sebanyak 3 entitas syariah.

Berkaitan dengan kegiatan pengawasan yang dilakukan oleh OJK pada tahun 2016 yang lalu, terdapat beberapa data tentang kepatuhan perusahaan asuransi syariah terhadap prinsip-prinsip syariah. Analisis laporan hasil pengawasan DPS, dilakukan terhadap 54 perusahaan perasuransian syariah yang wajib menyampaikan laporan. Berdasarkan hasil analisis, 53 perusahaan dinyatakan praktik operasionalnya telah sesuai dengan prinsip- prinsip syariah Islam, sedangkan 1 (satu) perusahaan lainnya dinyatakan belum sesuai dengan praktik prinsip-prinsip syariah Islam, yaitu berkaitan dengan penempatan dana investasi di bank konvensional, perhitungan dan pembagian surplus underwriting, serta penerbitan Surat Permintaan Penutupan Asuransi (SPPA) yang belum sesuai dengan prinsip syariah. Laporan hasil pengawasan DPS, disampaikan secara tahunan setiap tanggal 31 Maret tahun berikutnya. ${ }^{13}$

Merujuk kepada hasil pengawasan yang dilakukan oleh OJK, masih terdapat 1 (satu) perusahaan asuransi syariah yang ternyata dalam pelaksanaan usahanya belum sesuai dengan prinsip-prinsip syariah Islam, yaitu berkaitan dengan penempatan dana investasi di bank konvensional. Hal ini menandakan belum optimalnya peran DPS yang ada pada perusahaan asuransi syariah. Meskipun di tahun 2016 yang lalu hanya ada 1 (satu) perusahaan yang melakukan pelanggaran terhadap prinsip syariah, namun ini harus tetap menjadi perhatian serius agar kedepannya semua perusahaan asuransi syariah dapat menjalankan tugasnya sesuai dengan prinsip syariah.

Dalam praktiknya, Dewan Pengawas Syariah sebagai lembaga independen yang mengawasi operasional lembaga keuangan syariah menerima insentif maupun tunjangan dari entitas syariah yang di awasi dimana entitas tersebut masih memiliki hubungan adminstratif dalam struktur administrasi manajemen, yaitu bukan dari lembaga independen di luar administratif kepengurusan entitas yang tidak memiliki hubungan langsung secara adminstratif dalam strukstur organisasi yang mereka awasi, sehingga dari sinilah konflik kepentingan dapat saja terjadi dimana entitas syariah yang mereka awasi selalu ingin mendapatkan status pujian kesesuaian syariah namun disisi

\footnotetext{
${ }^{13}$ Laporan Perkembangan Keuangan Syariah tahun 2016, Otoritas Jasa Keuangan (OJK), hlm.128
} 
lain, Dewan Pengawas Syariah tidak ingin kehilangan jabatan dan insentif bulananya sehingga bisa jadi hanya melaporkan hal yang baik-baik saja terhadap entitas tersebut. ${ }^{14}$

Dewan pengawas syariah (DPS) memiliki peranan yang penting dan strategis dalam pengawasan syariah terhadap lembaga asuransi syariah. Pengoptimalan peranan DPS pada lembaga asuransi syariah merupakan hal yang sangat penting untuk memastikan setiap transaksi telah sesuai dengan prinsip-prinsip syariah yang merujuk kepada Alquran dan Hadis, yang dalam hal ini adalah fatwa dari Dewan Syariah Nasional Majelis Ulama Indonesia. Di dalam pedoman dasar DSN MUI Bab IV ayat (2) menyatakan bahwa "DSN MUI mengeluarkan fatwa yang mengikat DPS di setiap institusi keuangan syariah dan menjadi dasar bagi para pihak untuk mengambil tindakan hukum yang berkaitan, yaitu berdasarkan fatwa yang dikeluarkan DSN MUI dirujuk oleh DPS. Dewan Syariah Nasional (DSN) adalah satu-satunya badan yang mempunyai kewenangan mengeluarkan fatwa syariah terhadap jenis-jenis kegiatan, produk, dan jasa keuangan syariah, serta mengawasi pelaksanaan atau implementasinya fatwa tersebut oleh lembaga-lembaga keuangan yang ada di Indonesia.

Jika kita lihat dari sisi legislasi, keberadaan DPS telah disebutkan dan diatur dengan tegas di dalam peraturan perundang-undangan. Hal tersebut berarti ketentuan mengenai DPS telah memiliki landasan hukum . Ketentuan mengenai keberadaan DPS terdapat di dalam UU Nomor 40 Tahun 2007 tentang Perseroan Terbatas, UU Nomor 40 Tahun 2014 tentang Perasuransian, dan Peraturan Otoritas Jasa Keuangan (OJK) Nomor 73/POJK.05/2016 tentang Tata Kelola Perusahaan yang Baik Bagi Perusahaan Asuransi. Dalam Pasal 109 UU Nomor 40 Tahun 2007 tentang Perseroan Terbatas disebutkan bahwa:

1) perusahaan yang menjalankan usaha yang berdasarkan prinsip-prinsip syariah selain memiliki Dewan Komisaris memiliki Dewan Pengawas Syariah;

2) Dewan Pengawas Syariah sebagaimana dimaksud pada ayat (1) hendaklah terdiri daripada seorang pakar syariah atau lebih yang dilantik dan ditetapkan oleh Rapat Umum Pemegang Saham atas rekomendasi Majelis Ulama Indonesia;

${ }^{14}$ Khotibul Umam, Urgensi Standarisasi Dewan Pengawas Syariah dalam Meningkatkan Kualitas Audit Kepatuhan Syariah, Panggung Hukum: Jurnal Perhimpunan Mahasiswa Hukum Indonesia Cabang Daerah Istimewa Yogyakarta, Vol.1, No.2, Juni 2015, hlm.116 
3) Dewan Pengawas Syariah sebagaimana dimaksud pada ayat (1) akan memberikan petunjuk dan nasihat kepada Direktur dan mengawasi kegiatankegiatan perusahaan untuk mematuhi prinsip-prinsip Islam.

Berdasarkan ketentuan yang terdapat dalam undang-undang ini, artinya setiap perusahaan yang berbentuk Perseroan Terbatas (PT) harus memiliki Dewan Pengawas Syariah.

Ketentuan mengenai keberadaan DPS selanjutnya bisa kita lihat pada UU Nomor 40 tahun 2014 tentang Perasuransian. Undang-Undang tentang perasuransian tersebut merupakan perubahan terhadap UU Nomor 2 Tahun 1992 tentang Usaha Perasuransian. Perubahan tersebut dilakukan diantaranya adalah karena UU Asuransi yang lama tidak mengakomodir kepentingan terkait asuransi syariah. Di dalam UU Asuransi yang baru telah mengakomodir tentang keberadaan asuransi syariah serta DPS sebagai pengawas terhadap lembaga asuransi syariah tersebut. Dalam Pasal 60 ayat (2) huruf j UU Nomor 40 Tahun 2014 tentang Perasuransian menyatakan bahwa Otoritas Jasa Keuangan (OJK) berwenang untuk melakukan penilaian kemampuan dan kepatutan terhadap direksi, dewan komisaris, atau yang setara dengan direksi dan dewan komisaris pada badan hukum berbentuk koperasi atau usaha bersama sebagaimana dimaksud dalam Pasal 6 ayat (1) huruf c, dewan pengawas syariah, aktuaris perusahaan, auditor internal, dan pengendali. Kemudian selanjutnya di dalam Pasal 60 dijelaskan bahwa pemeriksaan yang dilakukan oleh OJK secara berkala dan/atau sewaktu-waktu, dimana DPS wajib memberikan keterangan data dan menyerahkan semua dokumen terkait kepentingan perusahaan. ketentuan tersebut artinya DPS selalu mendapatkan pengawasan secara ketat oleh OJK dalam menjalankan tugasnya. Selain itu, di dalam UU tentang Perasuransian ini juga terdapat sanksi bagi DPS yang dalam tugasnya nanti memberikan keterangan yang tidak benar atau membuat dokumen Palsu. Sanksi tersebut berupa sanksi pidana penjara dan pidana denda seperti yang terdapat di dalam Pasal 74 UU Nomor 40 Tahun 2014.

Dasar hukum terkait keberadaan DPS selanjutnya adalah Peraturan Otoritas Jasa Keuangan (OJK) Nomor 73/POJK.05/2016 tentang Tata Kelola Perusahaan yang Baik Bagi Perusahaan Asuransi. Pada peraturan OJK tersebut terdapat 10 Pasal yang mengatur mengenai ketentuan DPS, yaitu diatur dalam Pasal 35 sampai Pasal 45. Di dalam Pasal 35 ayat (1) menyatakan bahwa Perusahaan Asuransi Syariah, Perusahaan Reasuransi Syariah, dan Perusahaan Asuransi atau Perusahaan Reasuransi yang 
menyelenggarakan sebagian usahanya berdasarkan Prinsip Syariah wajib memiliki DPS. Kemudian di dalam ayat (2) dinyatakan bahwa DPS terdiri atas 1 (satu) orang ahli syariah atau lebih yang diangkat oleh RUPS atas rekomendasi Dewan Syariah Nasional Majelis Ulama Indonesia. Selanjutnya, pada Pasal 38 ayat (1) menyatakan bahwa DPS wajib melaksanakan tugas pengawasan dan pemberian nasihat dan saran kepada Direksi agar kegiatan usaha sesuai dengan Prinsip Syariah. Dan kemudian pada ayat (2) menyatakan bahwa Pelaksanaan tugas pengawasan dan pemberian nasihat dan saran yang dilakukan DPS sebagaimana dimaksud pada ayat (1) dilakukan terhadap:

a. kegiatan dalam pengelolaan kekayaan dan kewajiban, baik dana tabbaru', dana tanahud, dana perusahaan, maupun dana investasi peserta;

b. produk asuransi syariah yang dipasarkan; dan

c. praktik pemasaran produk asuransi syariah.

Berdasarkan ketiga landasan hukum tersebut di atas yang menjadi dasar keberadaan DPS pada lembaga keuangan syariah khususnya lembaga asuransi syariah, dapat dikatakan kedudukan DPS telah memiliki kekuatan hukum yang kuat sehingga DPS seharusnya dapat melaksanakan tugas pengawasan dengan sebaik-baiknya. Jika kita lihat dari analisis peraturan di atas, maka dapat kita ketahui bahwa tugas DPS tidak hanya mengawasi jalannya perusahaan tersebut saja, tetapi sampai kepada pengawasan terhadap produk asuransi yang dipasarkan dan praktik pemasaran produk asuransi syariah.

Posisi DPS adalah posisi yang strategis dan penting untuk menjamin bahwa bisnis syariah yang dijalankan oleh suatu lembaga keuangan syariah telah benar-benar berjalan sesuai dengan syariat Islam. Untuk mengoptimalkan peran DPS pada lembaga asuransi syariah, maka yang perlu mendapat perhatian adalah pada sisi Sumber Daya Manusia (SDM) dan kinerja. Anggota DPS yang pilih pada suatu lembaga keuangan syariah khususnya asuransi syariah diperlukan seorang pengawas yang tidak saja ahli atau mumpuni dalam bidang muamalah/bisnis syariah, tetapi juga dibutuhkan seorang pengawas yang memiliki beragam pengetahuan yang meliputi aspek hukum dalam KUHPerdata, KUHD, dan berbagai peraturan perundang-undangan seperti hukum kontrak, hukum perusahaan, hukum jaminan, hukum kepailitan dan lain sebagainya. Oleh karena itu, untuk mendapatkan DPS yang benar-benar berkualitas dibutuhkan mekanisme terkait recruitment DPS. 
Dalam praktik banyak anggota DPS direkrut bukan atas dasar pertimbangan kualifikasi di atas, tapi atas pertimbangan lain. misalnya saja bahwa mereka diletakkan di posisi tersebut dalam kapasitasnya sebagai ulama yang memiliki kharismatik dan ahli ilmu fiqh, padahal untuk menjadi DPS tidak cukup hanya mengandalkan kemampuan fiqh muamalah saja secara normatif, tetapi juga harus memiliki pengetahuan dalam bidang keuangan dan mekanisme operasional dalam asuransi syariah.

Berdasarkan hal-hal tersebut yang telah diuraikan di atas, ada beberapa solusi yang dapat mengoptimalkan peranan DPS pada lembaga asuransi syariah agar lembaga asuransi syariah yang ada di Indonesia dapat berkembang dengan pesat. Pertama, dibutuhkan regulasi khusus terkait Asuransi syariah. Saat ini pengaturan mengenai asuransi syariah masih menjadi satu dengan asuransi konvensional yang diatur dalam UU Nomor 40 Tahun 2014 tentang Perasuransian. Idealnya asuransi Syariah memiliki UU tersendiri seperti halnya Perbankan Syariah. Di dalam UU tersebut nantinya akan menjadi landasan hukum yang kuat bagi DPS untuk melakukan tugasnya sebagai pengawas lembaga asuransi syariah. Di dalam UU itu pula harus ditentukan tugas dan wewenang DPS serta memiliki sanksi hukum baik administratif maupun pidana apabila DPS tidak menjalankan tugasnya dengan baik atau menyimpang dari ketentuan. Walaupun peraturan yang ada saat ini sebenarnya sudah cukup bagus mengatur mengenai asuransi syariah dan DPS baik dalam UU maupun Peraturan OJK tetapi tetap saja asuransi syariah membutuhkan UU tersendiri.

Kedua, DPS yang dipilih atau diangkat pada lembaga asuransi syariah harus memiliki kemampuan atau kompetensi yang beragam seperti terkait ilmu fiqh muamalat, keuangan, menguasai operasional asuransi syariah, menguasai hukum kontrak, hukum perbankan serta memahami berbagai macam peraturan perundangundangan yang berkaitan dengan asuransi syariah. Jika pada suatu lembaga atau perusahaan asuransi syariah diangkat lebih dari satu DPS maka masing-masing DPS tersebut harus memiliki kompetensi yang berbeda sehingga masing-masing DPS tersebut dapat berkolaborasi dan saling melengkapi agar tercipta suatu kondisi yang ideal dalam menjalankan tugas pengawasan.

Ketiga, DPS dilarang rangkap jabatan lebih dari satu perusahaan. di dalam beberapa peraturan atau regulasi yang berkaitan dengan keberadaan DPS terdapat aturan berbeda mengenai jumlah maksimal rangkap jabatan bagi DPS. Ada 4 (empat) aturan industri keuangan syariah yang menimbulkan kebingungan bagi pelaku industri karena tumpang tindih dan tidak adanya harmonisasi peraturan. Keempat aturan 
tersebut antara lain Peraturan Bank Indonesia (PBI) No.11/3/2009 tentang Bank Umum Syariah, PBI No.11/10/2009 tentang Unit Usaha Syariah, Peraturan Menteri Keuangan (PMK) No.152/PMK.010/2012 tentang Tata Kelola Perusahaan yang Baik Bagi Perusahaan Perasuransian, serta Peraturan Ketua Badan Pengawas Pasar Modal dan Lembaga Keuangan (Bapepam-LK) PER.06/2012. Keempat peraturan tersebut sebagai bukti bahwa DPS boleh rangkap jabatan lebih dari satu perusahaan. Hal tersebut justru dapat berbahaya bagi industri Lembaga Keuangan Syariah (LKS) umumnya dan Asuransi syariah khususnya karena akan berdampak pada kerahasiaan perusahaan. Jika DPS mendapatkan atau mengetahui informasi penting yang ada di dalam perusahaan bukan tidak mungkin informasi tersebut akan menguntungkan bagi perusahaan kedua tempat DPS itu berada. Maka kerahasiaan perusahaan ini menjadi penting serta DPS akan menjadi lebih fokus melaksanakan tugasnya jika hanya menjadi DPS pada satu perusahaan.

Keempat, DPS harus berkolaborasi atau bekerja sama dengan pihak-pihak lain yang ada dalam perusahaan atau lembaga asuransi syariah. DPS dapat bekerja sama dengan Direksi, pegawai, maupun tenaga ahli profesional dalam melakukan tugasnya. Hal ini dimaksudkan agar ada komunikasi yang baik dari semua pihak yang ada dalam lembaga asuransi syariah tersebut sehingga dapat mewujudkan tujuan yang hendak dicapai. Selain itu, DPS juga harus berani menegur pengelola lembaga atau perusahaan asuransi syariah jika dalam pelaksanaannya terdapat penyimpangan dari prinsip-prinsip syariah. Jika DPS bertindak cepat dalam memberikan nasihat kepada direksi atau pengelola lembaga asuransi syariah, maka kedepannya dapat memperbaiki dan meningkatkan citra bisnis syariah khususnya asuransi syariah di mata masyarakat. 


\section{E. Kesimpulan}

Untuk mengoptimalkan peran DPS pada lembaga asuransi syariah yang dapat dilakukan antara lain: Pertama, dibutuhkan regulasi khusus terkait Asuransi syariah untuk memperkuat keberadaan DPS. Kedua, DPS yang dipilih atau diangkat pada lembaga asuransi syariah harus memiliki kemampuan yang beragam satu sama lain terkait ilmu fiqh muamalat, keuangan, menguasai operasional asuransi syariah, maupun pemahaman mengenai ilmu hukum. Ketiga, DPS dilarang rangkap jabatan lebih dari satu perusahaan. Keempat, DPS harus berkolaborasi atau bekerja sama dengan pihakpihak lain yang ada dalam perusahaan atau lembaga asuransi syariah serta DPS harus berani menegur pengelola lembaga asuransi syariah jika produk yang ditawarkan maupun kegiatan usaha yang dilakukan tidak sesuai dengan prinsip-prinsip syariah. 


\section{DAFTAR PUSTAKA}

Amran Suadi, Abdul Manan Ilmuan dan Praktisi Hukum (Kenangan Sebuah Perjuangan), (Jakarta: Kencana, 2016).

AM. Hasan Ali, Asuransi dalam Perspektif Hukum Islam (Suatu Tinjauan Analisis Historis, Teoritis, dan Praktis), (Jakarta: Kencana, 2004)

Akhmad Faozan, Optimalisasi Peran Dewan Pengawas Syariah Pada Lembaga Keuangan Syariah, Jurnal Ekonomi Islam, el-Jizya Vol.II, No.1, Janauari 2014.

Bagya Agung Prabowo dan Jasri Bin Jamal, Peranan Dewan Pengawas Syariah terhadap Praktik Kepatuhan Syariah dalam Perbankan Syariah di Indonesia, Jurnal Hukum IUS QUIA IUSTUM, Vol.24, No.1, 2017.

Eko Adi Widyanto, Peran Independensi Dewan Pengawas Syariah Terhadap Loyalitas Penerapan Syariat Islam, Jurnal Eksis, Vol.6 No.2 , Agustus 2010:1440-1605.

Khotibul Umam, Urgensi Standarisasi Dewan Pengawas Syariah dalam Meningkatkan Kualitas Audit Kepatuhan Syariah, Panggung Hukum: Jurnal Perhimpunan Mahasiswa Hukum Indonesia Cabang Daerah Istimewa Yogyakarta, Vol.1, No.2, Juni 2015.

Uswatun Hasanah, Asuransi dalam Perspektif Hukum Islam, Jurnal Ilmu Syari'ah dan Hukum, Asy-Syir'ah Vol. 47, No. 1, Juni 2013

Laporan Perkembangan Keuangan Syariah tahun 2016, Otoritas Jasa Keuangan (OJK).

\section{Peraturan Perundang-undangan}

Undang-Undang Nomor 40 Tahun 2007 tentang Perseroan Terbatas.

Undang-Undang Nomor 40 Tahun 2014 tentang Perasuransian.

Peraturan Otoritas Jasa Keuangan (OJK) Nomor 73/POJK.05/2016 tentang Tata Kelola Perusahaan yang Baik Bagi Perusahaan Asuransi. 